Covered in: Web of Sciences (WOS); EBSCO; ERIH+; Google Scholar; Index Copernicus; Ideas RePeC; Econpapers; Socionet; CEEOL; Ulrich ProQuest; Cabell, Journalseek; Scipio; Philpapers; SHERPA/RoMEO repositories; KVK; WorldCat; CrossRef; CrossCheck

2019, Volume 10, Issue 1, pages: 68-99 | doi: https://doi.org/10.18662/po/56

\section{Philanthropical Practices and Professionalization of Social Assistance in the Orthodox}

\section{Church. A}

\section{Specialist's}

Perception

\section{Polixenia NISTOR ${ }^{1}$}

${ }^{1} \mathrm{PhD}$ Student, Doctoral School of Sociology, "Al. I. Cuza” University of Iasi, Romania, polixenianistor@yahoo.com

\begin{abstract}
The article presents a research based on a sociological inquiry through a questionnaire regarding the views of the persons involved - priests, social workers and volunteers - in the socio-philanthropic activity of the Romanian Orthodox Church as a faith-based organization, on the social and spiritual dimensions of their own socialphilanthropic and social assistance practice, and on the perceived impact of their professionalisation on the specificity and quality of the services provided. The research was carried out between September 2018 and February 2019 in the Archdiocese of Iaşi, which consists of 13 deaneries and 1221 parishes, disposed on the territory of Iasi, Neamţ and Botoşani Counties. The most important results of this research show that the social-philanthropic activity of the Orthodox Church is correlated with the liturgical one, the spiritual dimension being added to the assistential one, while the philanthropic and assistential activities are seen by the professionals as a continuum of the active practice of Orthodoxy in the form of Christian social assistance, which can make us conclude that the assistential organizations within the Orthodox Church in Romania may be, in general, with the exception of certain peculiarities, framed within the faith-permeated organizations typology.
\end{abstract}

Keywords: philanthropy; professionalization; social assistance; Orthodox church.

How to cite: Nistor, P. (2019). Philanthropical Practices and Professionalization of Social Assistance in the Orthodox Church. A Specialist's Perception. Postmoderm Openings, 10(1), 68-99. https://doi.org/10.18662/po/56 



\section{Introduction}

Nowadays, there is an increasing awareness of the post-secular society, as a society resulting from the failure of the anti-religious policies carried out by so-called secular societies, which failed in the activity of removing religious elements from the public discourse (Gavriluţă, 2011; Sandu \& Caras, 2013). In the last decade, the complete and absolute separation of roles between the state and the Church is questioned (Cojocaru, Cojocaru, \& Sandu, 2011; Gavriluță, 1998, 2002; Frunză, 2012) due to the increase of the role of religious movements in the formation of the public agenda and in the background of the process of democratic deliberation (Nistor, 2019).

Faith-based organizations, as providers of charitable services, as well as professional social assistance, are defined as private entities, religious cults or particular units of a religious cult, as well as non-governmental organizations affiliated to religious cults, that provide social services or carry out a charitable activity in favor of categories of disadvantaged persons who, most of the time, belong to those denominations (Sider \& Unruh, 2004). The efficiency and effectiveness of the services provided by these organizations has begun to be analyzed after the recurrence of the religious element at the forefront of the public discourse and the recognition of the partial failure of the policies of forced separation of social services from the religious element and their secularization. This trend, started in the US, quickly became a reality in Europe, where religious communities were reconsidered as partners of public social services.

The purpose of this research is to clarify the specificity of the sociophilanthropic activity of the Romanian Orthodox Church and to develop a model of Christian social assistance, originated in faith based social action, as a particular form of expression of social action based on faith and specific for Orthodoxy.

The objectives of this research are: to identify the specificity and significance attributed to the socio-philanthropic activity of the Romanian Orthodox Church in different environments of the Archdiocese of Iaşi; to identify the meanings attributed to the professionalisation of charity, correlated with the professionalization of social services of the Romanian Orthodox Church; to identify the particularities of the professionalisation of social services offered by the Romanian Orthodox Church in the Archdiocese of Iaşi: to clarify the role of the priests in the process of combining philanthropy with professional services. 


\section{Postsecular society}

In present society, religion can not remain exclusively in the private sphere, as religion is being recalled to assume its place in the public sphere. Jurgen Habermas (2008) and, together with him, a series of other thinkers (Brieskhorn, 2010: 24-35; Reder, 2010: 36-50; Ricken, 2010: 51-58), consider that society has reached the point where it has to relinquish militant secularism, as it is prepared to recognize and respect the role of religion in the public sphere. This imperative and unrealistic absence of the voice of religious persons in the conduct of communicative action, through public dialogue generating consensus at the social level, is an element of democratic deficit, in the sense that Habermas constructs the term. The lack of representativeness of some institutions that are appointed by the representatives of power, without being a subject to democratic control by vote - in the present case, and eliminating consultation partners and religious stakeholders, harms the idea of deliberative democracy.

The debate on the participation of religious oriented stakeholders (we will continue to use the term "faith-based organizations" to denominate these stakeholders, including cults, but also other civil society organizations that have or claim to have a present or historical religious affiliation) is linked to the attempt to provide an answer to the question which should be and which actually is the place of faith-based organizations and, through them, of religion in present society. Braeckman points out that the debates on the role of religion in the public sphere are primarily about the moral cognitive and epistemic contents of religion, when in fact the fundamental dimension of any religion is its ability to build communities from a symbolic point of view thus establishing them from an identity perspective (Braeckman, 2009: 279-296). The deconstruction of charity in the postsecular post-modern society aims at moving from a model of charity based on philanthropy to the one of the assistential state, based on socialinstitutionalized and mandatory solidarity, as well as on the professionalisation of social assistance.

The post-secular understanding of the particularities of social assistance provided by Christian organizations allows the construction of a working hypotheses that, in a post-secular society, charity professionalization occurs through the development by faith-based organizations, in the continuation and completion of philanthropic activities, that do not disappear, of professional social assistance services, based on the humanist vocation of social assistance and a series of particular values of a Christian nature, but which are customized to be in line with the general social assistance principles. 
Social assistance provided by faith-based organizations is carried out within the limits of quality standards imposed by the state, but the particular emphasis on the value of the beneficiary as a person, communication and communion with him is what distinguishes professional practice based on religious values, from the one based on secular values.

As we have shown in a previous article (Nistor, 2018a), there are researches that attempted to advance a theoretical model of post-secular social assistance, having as a starting point the spiritual rhetoric, which, even if it is caracterized as such, is not necessarily religious. These models have been compared to those of a modern, liberal, secular nature. When overlapping the two models, it is noticed that there is a common element between the practice of social assistance and faith-based social action, in the sense that the persons involved in the provision of services both in one case and in the other criticize the neo- liberal welfareist approach and rather agree with practices derived from the model of the ethics of care (Gilligan, 1989).

\section{Faith-based organizations}

Resizing of philanthropy and social assistance in faith-based organizations was based on the United States legislation of 1996 (Law No. 104-193 on Personal Responsibility and the Harmonization of Employment Opportunities), a model which then met a widespread dissemination, or which has been the inspiration for legislation and practice in many other states.

The American Law (Nistor, 2018b) has implicitly recognized the social importance of charitable work by correlating it with the social one, emphasizing in this regard the role of faith-based organizations (1996), through the provision entitled "The Charitable Choice". The law infuses the market for this type of services, in the sense that it allows the combination of ecclesial and secular social services, given the possibility for faith-based organizations to access public funding, which significantly changes the historical relationship between the religious community and the public sector (Cnaan \& Boddie, 2002).

In the scientific literature (Cnaan \& Boddie, 2002) it appears that until the law in the United States was enacted, the number of faith-based organizations that applied for public funding was low and this situation did not change significantly even after the law entered into force. Conclusions regarding the reasons which have caused this phenomenon are determined by the reasoning that there is a lack of information that characterizes the activity of persons responsible for the financial aspects of the respective organizations of the manner in which they can access public funds (Ticu, 
2013) or, in other words, there is a conservative reticence, generated by the resistance imposed by religious integrity (Cace, Cace, \& Nicolăescu, 2011), more precisely the opposition to laicization, which is the precise reason why public-private partnerships in the provision of social services are very difficult to implement.

Sider and Unruh (2004) attempt to define the notion of faith-based organizations and carry out a classification of these organizations, while pointing out the difficulties faced by authors in providing a definition of the concept with a high degree of scientific acceptability, since the analysis of the types of social services offered by these organizations, as well as their efficiency reveals the lack of a clear demarcation between secular and religious services, probably due to the multitude of existing types of OBC and the religious specificity of each of them.

Religious belief plays an important role in the OBC's characterization, and Sider and Unruh (2004) show that this analysis must be started after a clear identification of the role religion plays in the emergence and development of faith-based organizations, in order to analyze the type, the methods of implementation and the effects of social programs and service provision, at which time it will be possible to state that in some OBCs, the religious dimension is under-dimensioned and in others it is oversized, an aspect also accepted by other authors in the literature (Van der Merve, Swart, \& Hendriks, 2014).

We believe that the religious side of a faith-based organization has a multidimensional dimension (Nistor, 2018c), in agreement with the authors suggesting a classification of these organizations based on the importance given to elements of religiosity within the organization, and so we can distinguish between organizations that are heavily infused with a religious content, those that are in an intermediate situation and, finally, those that have affiliated themselves with a religious faith in the past, but that are currently operating in a secular manner (Van der Merve et al., 2014: 110-116).

Next, we will describe the manner in which Sider and Unruh (2004) characterize what they call faith-permeated organizations and show that the classification made by these authors includes five categories of OCBs, but in this paper we will not focus our attention on all five, since the model of faith-based organizations providing social assistance and philanthropy for the Romanian Orthodox Church that results from our research is the one consistent for faith-permeated organizations.

This type of organization has the following characteristics: the close correlation between the services provided or offered within the organization and the religious element; the fact that social programs are the continuation of 
religious teachings, more precisely the practical expression of the religious doctrine adopted by the organization; the staff involved in the provision of services is essentially religious, and the recipients (either because this is a requirement or by their own choice) are part of the same religious congregation; the decision-makers within the organization are also, in most cases, decision-making hierarchs within the Church; the participation of beneficiaries and employees in the religious programs provided by the organization is mandatory, and there is the belief that without such participation, the social or philanthropic beneficial purpose of the organization will not be achieved; the funding of programs is largely devoted to religious affiliation; there is a reluctance of the organization to cooperate with other organizations, whether they are secular or they belong to other religions (Cojocaru et al., 2011; Van der Merve et al., 2014; Sider \& Unruh, 2004).

\section{Research hypotheses}

Hypotheses H1 - The social-philanthropic activity of the Romanian Orthodox Church is correlated with the liturgical one.

Hypotheses H2 - The social-philanthropic activity of the Romanian Orthodox Church is based on the model of faith-permeated organizations.

Hypotheses H3 - Professionalization of social-philanthropic and assisting services within the Romanian Orthodox Church is done by adding a spiritual dimension to the secular values of the assistential professions.

Hypotheses H4 - Social-philanthropic activity and specialized social assistance are seen as a continuum, as they are distinguished mainly by the level of participation, rather than by the degree of professionalization of services.

Hypotheses H5 - Professionalization of social services is seen as a risk of secularization.

\section{Methodology}

The research was carried out between September 2018 and February 2019 in the Archdiocese of Iaşi, which consists of 13 deaneries and 1221 parishes, disposed on the territory of Iasi, Neamţ and Botoşani Counties. The universe of research was made up of representatives of the Romanian Orthodox Church involved in social-philanthropic services, namely priests, deacons, monks, social workers, members of the parish committees, volunteers and other persons involved in the social-philanthropic activity of the Romanian Orthodox Church. The sample was made out of 581 people, representing a statistically representative sample. Four questionnaires were excluded from the 
Philanthropical Practices and Professionalization of Social Assistance in the ...

Polixenia NISTOR

sample as invalid (they were not filled in or very little filled in), so the analysis of the results was done for a number of 577 valid questionnaires.

Mitropolia Moldovei și Bucovinei Arhiepiscopia Iaşilor

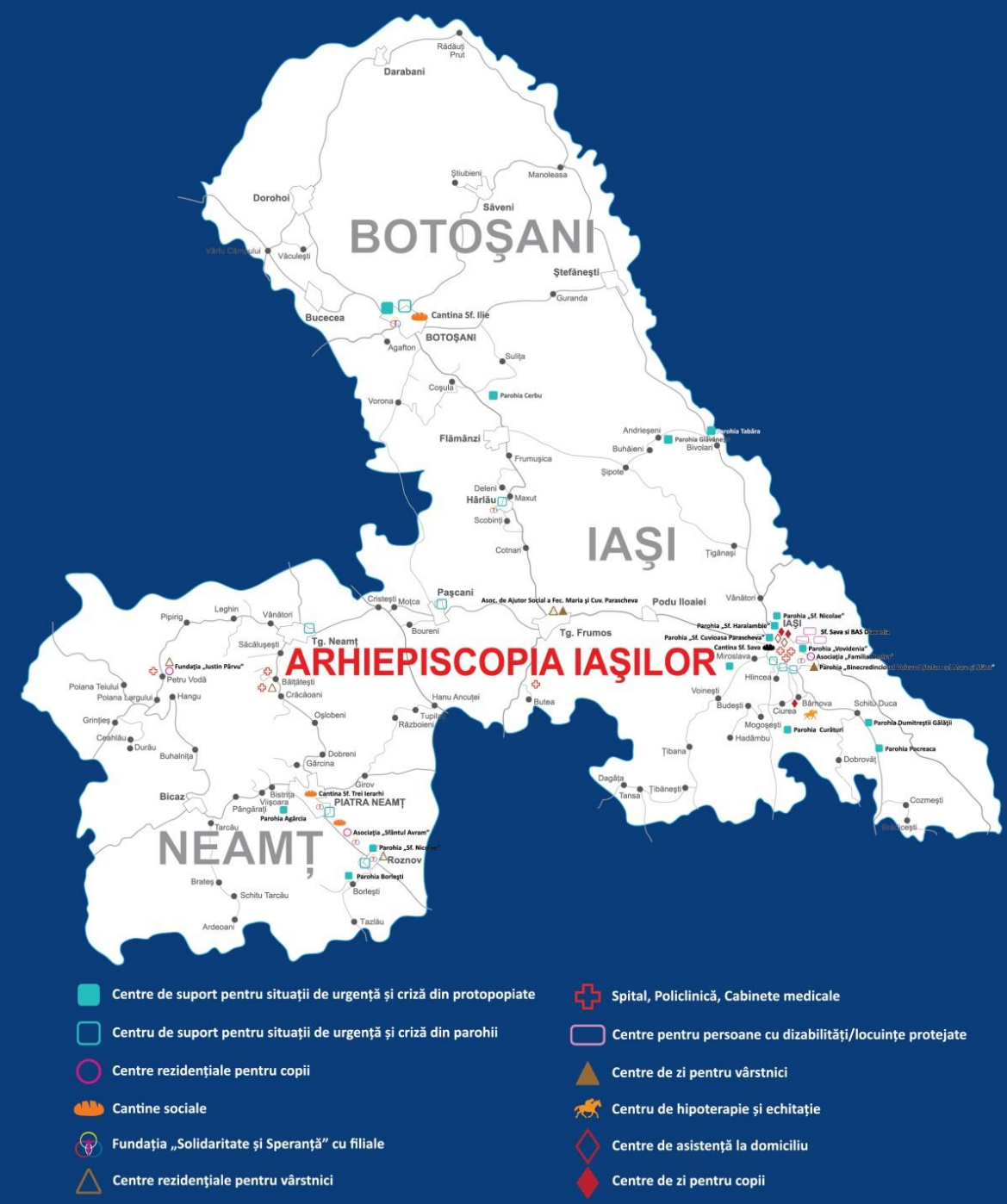

Figure 1 - Map of social-philanthropic services in the Archdiocese of Iaşi 


\section{Sampling}

The sample was selected using the snowball method, the questionnaires were applied to all persons participating in the monthly meetings with the priests in the deaneries, the participants were invited to fill in the questionnaires during these meetings, and also the participants (priests) who accepted were invited to apply the questionnaire to the other persons involved in the social-philanthropic activity in their parishes, thus exercising the role of survey operators. The questionnaires were then applied and in the end transmitted to the author of this article. Priests who have acted as surveyors have received a minimum of training with regard to applying the questionnaire, including ensuring they received informed consent from respondents.

All persons who participated in the research were informed about the implications participating, as well as the possibility to withdraw from the research or not to answer a certain question, and continuing the questionnaire was considered informed consent.

The sample includes 439 men and 130 women, and 8 people declined to declare their gender. Of the total sample, 97\% are Christian-Orthodox, $2 \%$ say they are not religious and $1 \%$ did not want to respond. The existence, even of a proportion of $2 \%$, of persons who declared themselves agnostic shows that, as a whole, the Church does not necessarily require belonging to the Orthodox Christian faith to carry out philanthropic activities, generally volunteering activities, in its framework. It is highly probable that the selection also operates in the opposite direction, as people of different denominations than Christian Orthodox prefer to work in faith-based organizations affiliated with their own religious convictions, and this is why which they do not require involvement in Orthodox Christian organizations. In the case of agnostic persons, it is assumed that they will choose secular organizations in which to carry out their social-philanthropic activity.

The small number of people who do not declare their religious affiliation is to be expected given that we are talking about socialphilanthropic activities carried out by the Church, but also about the twostep sampling method described above. However, we can consider that, in general, the social-philanthropic activities of ROC is based on the model of faith-permeated organizations that, even if they do not necessarily impose as a condition an affiliation to the Orthodox Christian faith, they prefer to select participants for such activities among their own parishioners.

Of the total respondents, 43 are 18 to 25 years of age, 304 are between 25 and 45 years of age, 226 are over 40, and 14 did not want to declare their 
age. The survey participants come from both rural (327 people) and urban (232 people) communities, and 8 people refused to answer the question. One person declared that he/she does not have any education, 1 person is a graduate of 8-grade gymnasium, 12 of the mandatory 10 grades, 39 have high school education, 8 have professional studies, 20 post-graduate, 359 are graduates of higher education, 139 have postgraduate studies, and 6 people did not state which studies they completed. 97 of the respondents are unmarried, 454 are married, 16 are divorced, and 10 are unwilling to respond.

The large number of married persons can be explained by the fact that in the first stage of applying the questionnaire, the respondents were exclusively Orthodox priests, but also that one of the fundamental values promoted by the Romanian Orthodox Church is family life, which explains the increased percentage of married persons in the sample. This is correlated with the fact that the vast majority of respondents (530 persons) are aged over 25, the age at which traditionally Orthodox people start a family, and of these 226 are over 40 years of age, when Christian-Orthodox values urge Christians towards philanthropy, focus on care for the others, self-giving to the community and those in need, while during the first stages of life, it is recognized that young people have a predisposition to focus on their own projects for the future.

As we can observe in Figure 2, there is a correlation between the age structure of the sample and the quality of the people involved in philanthropic activities, of which $67 \%$ are priests, $15 \%$ volunteers, and $10 \%$ social workers, which represent the vast majority of those carrying out such activities in the Romanian Orthodox Church, the rest of the interviewed categories representing only 3\% (members of the parish committees), $2 \%$ (other categories and the same percentage of people who did not want to responds), respectively $1 \%$ (deacons).

What we notice is that the age of persons involved in philanthropic and social assistance activities of the Romanian Orthodox Church is relevant in view of the fact that these people, in one way or another, are professionals. Whether they are priests (being a priest meaning to have what is commonly referred to in Orthodoxy as a "calling", in the sense of a spiritual predisposition, but also to have specialized training, an aspect also revealed by the structure of the sample - out of 439 men, 399 are priests, of whom 278 have higher or post-university education), professional social workers or volunteers (among other things, volunteer work is done by people who want to gain professional experience for employment in specialized services, and in the sample 31 volunteers are between 18 and 25 years of age, out of a total of 43 respondents aged between 18 and 25, so we 
can assume that they do not volunteer for philanthropic reasons alone, and it is most likely that they are also interested in their own professional training in the field of social work), we can say that the motive we have a high percentage of respondents who are involved in social work activities within the Romanian Orthodox Church who are over 25 years of age is also explained by the fact that people who have undergone vocational training and gained a professional status have greater openness to engage in such activities, their pro-social behavior being favored by their professional status.

\section{Results and data interpretation}

Even if usually the distinction between social philanthropy and social assistance services is primarily concerned with the existence or non-existence of accredited and/or licensed services, we find a fairly high degree of professionalization of all social-philanthropic services within the Romanian Orthodox Church, due to the high degree of participation of people with higher education and vocational training, of which $10 \%$ are also professional social assistants.

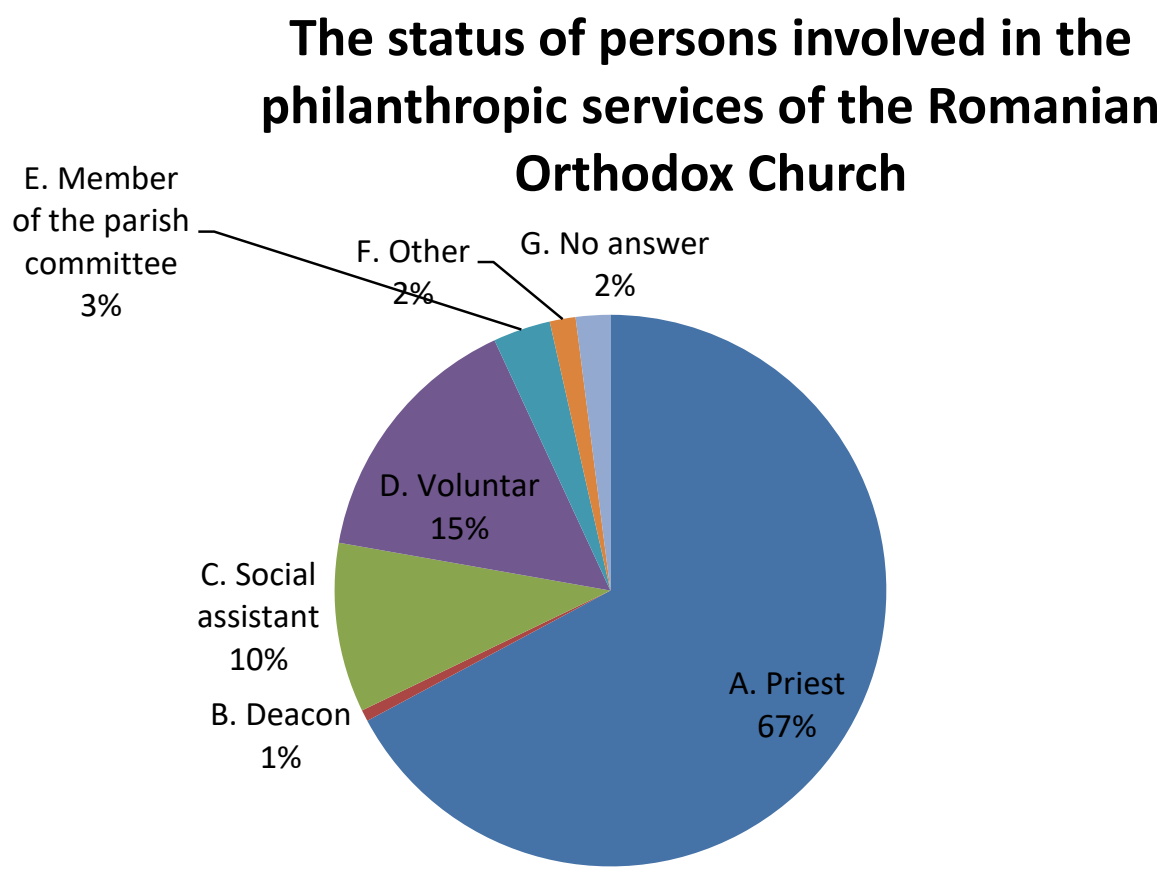

Figure 2 - The status of people involved in social and philanthropic activities offered by the Romanian Orthodox Church 
Within the social-philanthropic activities carried out by the Romanian Orthodox Church, humanitarian aid, in the form of financial aid or goods, including food, clothing, school supplies etc., is predominant, according to the opinion of the survey participants. Another church-based activity in which respondents are involved, being the second most frequent one, is providing help in building/repairing/arranging houses for the needy $(17 \%)$. We find that material social benefits account for a total of $56 \%$ of the volume of social-philanthropic and assistance activities of the Romanian Orthodox Church.

Licensed or unlicensed social service activities consist of caring for the sick/elderly people at their home (15\%), shopping aid for sick/elderly people $(12 \%)$, social assistance services (specialized) in crisis situations $(6 \%$ ), social care/assistance in day care centers (5\%), social care/assistance in specialized establishments (residential centers) (3\%), $2 \%$ of the participants in the survey answered "other services" and 1\% refused to answer. Of the $2 \%$ who responded "other services", they mentioned that such services were: helping pregnant women during their pregnancy, offering liturgical and confessional services, engaging in a liturgical, catechetical and confessional programs, psychological counseling and family therapy, activities and material aids with and for children in special schools (mentally, physically or hearing-impaired), social canteen or Sunday meals for needy people, offering of firewood. 


\section{The type of social-philanthropic activities in which the person is involved}

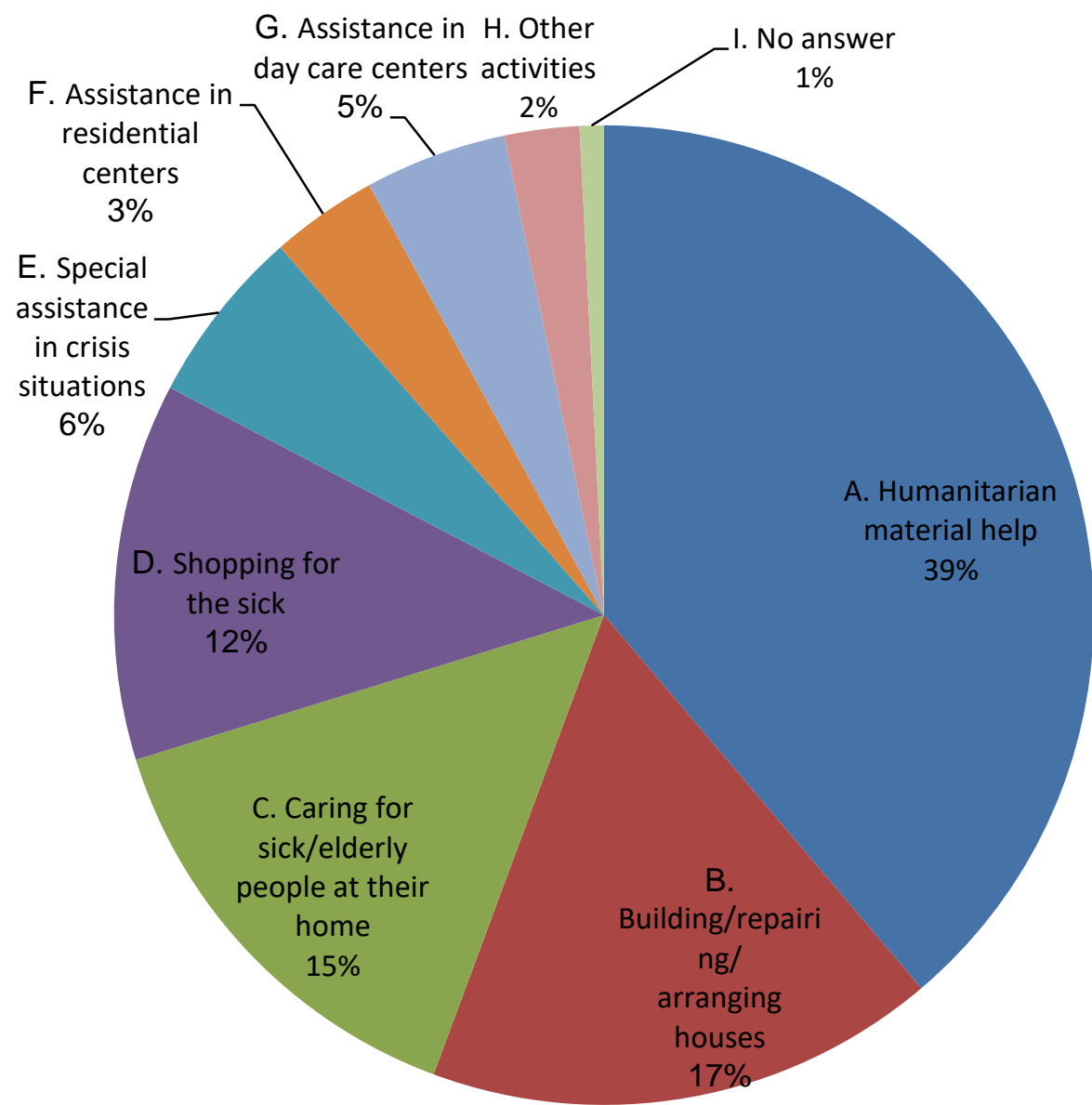

Figure 3 - Type of social-philanthropic activities in the Romanian Orthodox Church

As regards to the degree of religiosity of the respondents, measured in the frequency of participation in religious activities, it ranges from $75 \%$ who say they go to church several times a week, up to $1 \%$ who say they never go to church, with an intermediate rate of $19 \%$ showing that they 
constantly go to church, but the degree of participation is fluctuating (12\% once a week, $5 \%$ once a month, $2 \%$ during important religious celebrations). $5 \%$ of respondents declined to answer the question.

The very large number of people who say they go to church several times a week or even once a week $(87 \%)$ show that the motivation of philanthropic activity is of a spiritual nature, with an obvious correlation between the frequency of participation in religious rituals and engaging in philanthropic and assisting activities. On the other hand, this correlation is expected in view of the structure of the sample, of which $67 \%$ are priests, but there are $20 \%$ who are not priests who still go to the church several times a week or at least once a week, which validates the assertion that social-philanthropic activity within the Romanian Orthodox Church is closely correlated with the liturgical one. Therefore, hypothesis H1 is validated.

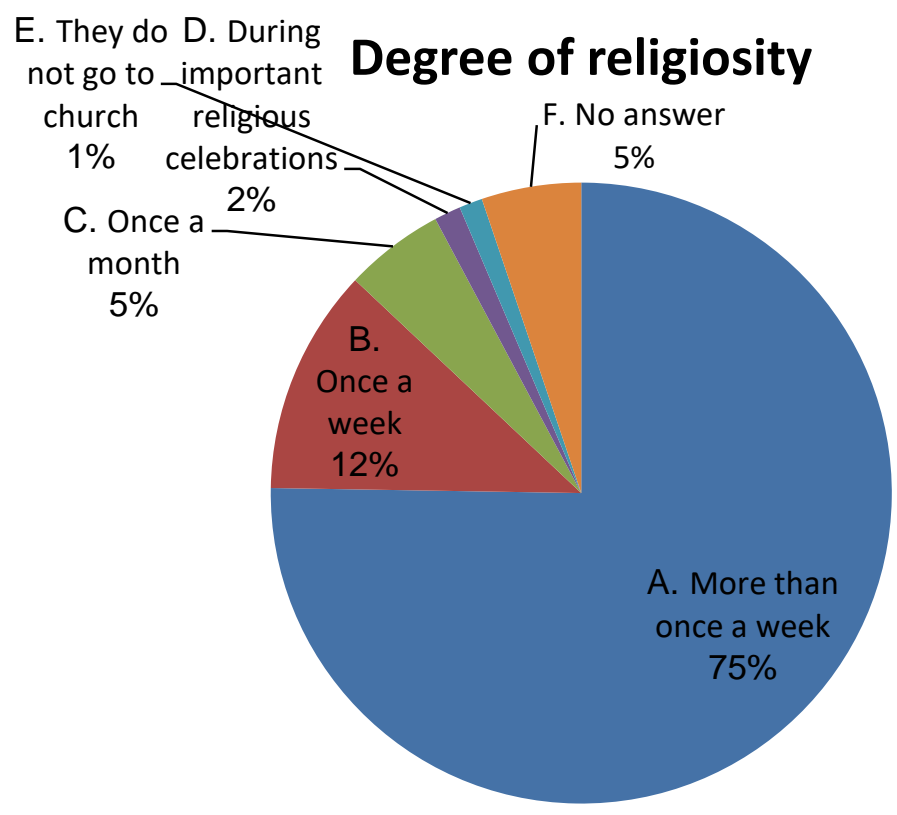

Figure 4 - The degree of religiosity of respondents

Regarding the reason that motivates them to participate in socialphilanthropic activities organized by the Romanian Orthodox Church, 33\% say that this is the feeling of moral duty towards other fellow human beings, $29 \%$ are stimulated by a sense of compassion or sympathy towards the 
persons in difficulty, $12 \%$ have the belief that if they do good, this good will be rewarded by another form of good, $11 \%$ say they do these activities because that is their job, $7 \%$ because they have been asked to get involved, $4 \%$ because they have found opportunities for volunteer work/practice/internship, $2 \%$ say that other reasons were the determinants, and $2 \%$ did not want to respond.

We notice that $52 \%$ of respondents are involved due to the sense of duty and mercy towards fellow human beings, fundamental values promoted by the Church, thus the answers to this question corroborates with the previous conclusion, that the $\mathrm{H} 1$ hypothesis is validated. The liturgical practice thus has a living continuity with the social one, both being in fact a confession of faith, both through prayer and deed. Although the sense of duty towards fellow human beings, mercy and compassion can be regarded as expected to be a determinant motivation for a sample in which $67 \%$ of the respondents are priests, it will be noticed that in reality we can extend the conclusion that duty towards fellow human beings, mercy and compassion are the determining factors for most of the people involved in the social-philanthropic activities of the Romanian Orthodox Church, even if they are not part of the clerical structures themselves, since the percentage of priests who said that for them the sentiment of duty is the determinant reason is $69.92 \%$ of all priests and $48.35 \%$ of all respondents, and the percentage of those who affirmed that mercy and compassion is the determining factor is $56.89 \%$ of all priests, which represents $39.34 \%$ of all respondents. So, the priests who responded that they are motivated by both factors (the sense of duty, but also mercy and compassion) is $35.54 \%$ of all priests and $23.22 \%$ of the entire sample.

A fairly high percentage of interviewees who are not priests feel motivated to undertake philanthropic activities in the framework organized by the Romanian Orthodox Church based on these fundamental ChristianOrthodox values, given that $33.51 \%$ of them state that they feel motivated by the feeling of duty towards their fellow human beings, and $27.37 \%$ of them by the feeling of compassion and mercy. We conclude that priests have a higher social conscience, motivated by their church zeal, which confirms, in their case, both hypotheses, the one according to which socialphilanthropic activity within the ROC is based on a faith-permeated organization model, as well as the one according to which this activity constitutes a continuum with the liturgical activity of the Church.

Among those who are not priests (179 persons, representing $31.02 \%$ of the total number of interviewed persons), $37(20.67 \%)$ show that they were motivated to engage in social-philanthropic activities by the fact that 
they were asked to get involved, $34(18,99 \%)$ claim that their motivation lies in the fact that it is their job, $26(14,52 \%)$ that they are convinced that by doing a good deed, this good will return, $18(10,05 \%)$ that within philanthropic or social assistance organizations of the Romanian Orthodox Church they have found opportunities for volunteer work/practice/internship, and 2 people $(1.11 \%)$ say they have other motivating reasons, namely the pleasure of helping as part of a team, development opportunities and love for fellow human beings.

The small percentage of those who declare themselves involved in social-philanthropic activities due to professional requirements show that this activity is treated in the Church as a vocation rather than a profession. Of the 98 respondents who considered their participation in socialphilanthropic activities to be their professional activity, only 27 (ie $27.55 \%$ of them) chose professional motivation as the only motivation for their participation in social-philanthropic activities, while others added one or more of the following reasons: the sense of moral duty towards others, the feeling of compassion or mercy towards people in difficulty, the belief that by doing good, that good will return, the fact that they have been asked to get involved. This leads us to at least a partial validation of hypothesis number $\mathrm{H} 3$, according to which the professionalization of socialphilanthropic and assistential services within the Romanian Orthodox Church is done by adding a spiritual dimension to the secular values of the assistential professions.

Regarding people who have declared themselves involved in socially philanthropic activities because they have been asked to do so, we can assume that they make "obedience", a specific value of the Christian Church in general and of the Orthodox one in particular, who is usually encountered in the activity of monks, but that can also be made by Christians who are not monks and who assume to give a positive response to the suggestions of the hierarchs, which transforms a voluntary activity into an effective spiritual practice. This also partially confirms the hypothesis that Christian socialphilanthropic practice is professionalized by adding a spiritual dimension to secular social practice (hypothesis H3). 


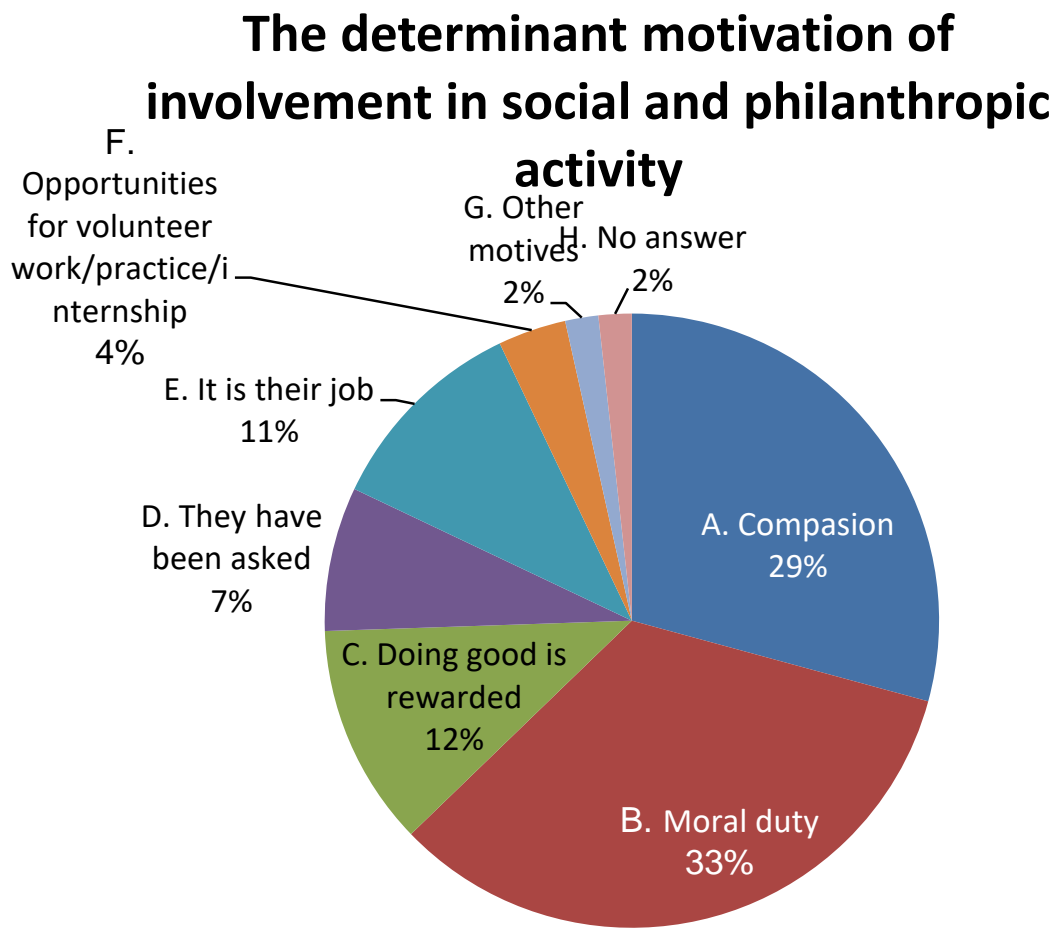

Figure $\mathbf{5}$ - The determinant reason for involvement in the socialphilanthropic activities of the Romanian Orthodox Church

Being asked to characterize their involvement in social and philanthropic activities, $35 \%$ of respondents show that this is a duty of every person, irrespective of religion, $28 \%$ that it is a duty of every Christian, $22 \%$ that it is a good deed, pleasing to God , but not necessarily a duty, $14 \%$ that it is a duty of the Church's servants, $1 \%$ refused to answer the question, and no respondent felt necessary to supplement its characterization with elements other than those mentioned in the questionnaire.

We note that the feeling of duty motivates $33 \%$ of respondents whether it is considered to be general human duty or to be mainly a Christian-specific one. The percentage of those who consider moral duty to be the main cause of their need to engage in social-philanthropic activities is practically double than of those who assume this duty as a reason for their own involvement in social and philanthropic activities $(33 \%)$. This is due to the fact that besides the feeling of duty, Christian 
mercy intervenes as a motivational factor of social involvement. From our point of view, this factor is superior from the point of view of Christian morality to the feeling of duty, that acts somewhat as a constraint, while mercy causes action not only voluntarily, at the mental level, but also as an intrinsic motivation based on one's own feelings. It is noteworthy that $22 \%$ of respondents believe that engaging in charitable activities is not a duty, but a way of doing good. For $14 \%$ of respondents, the duty to participate in social-philanthropic activities is a concrete, professional responsibility for Church servants. This seems to correlate with $7 \%$ of respondents who said they participate in social-philanthropic activities by doing "obedience" or positively responding to suggestions/requests. However, the correlation is weak, with a correlation index of $+/-0.3$.

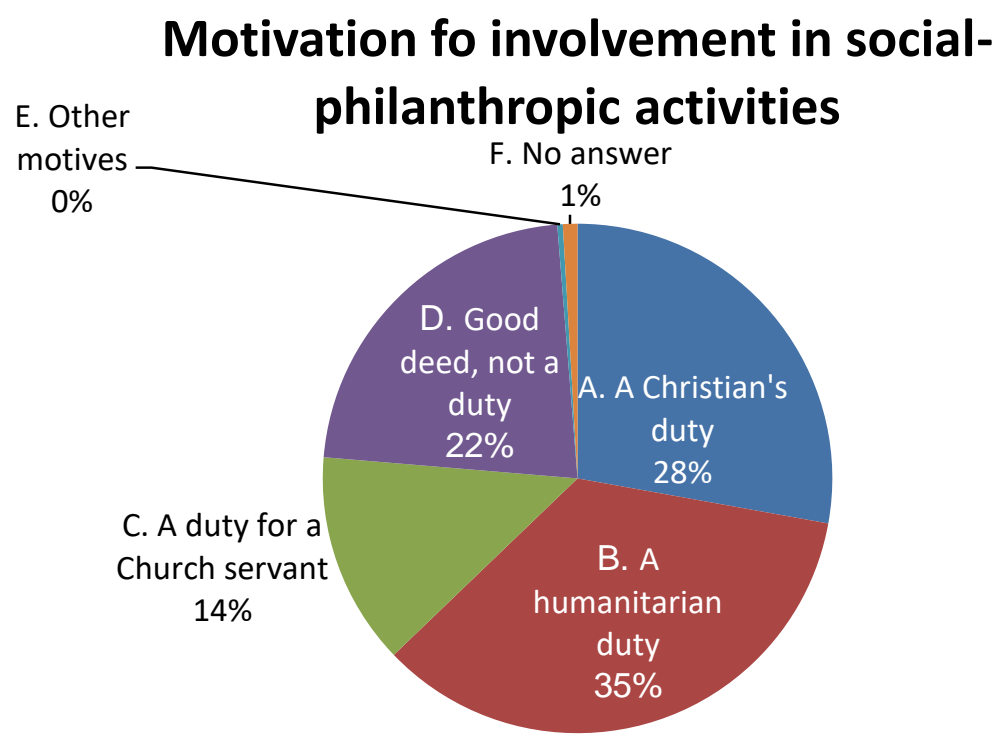

Figure 6-Motivation for involvong in social-philantrophic activities

Regarding the status of beneficiaries of social-philanthropic activities of the Romanian Orthodox Church, the respondents show that $27 \%$ of them are people in need, regardless of religious belief, 25\% are parishioners who frequently participate in the spiritual life of the parish, an identical percentage say that beneficiaries are members of the religious community, irrespective of the parish, $21 \%$ are persons in need from the parish, irrespective of religious affiliation, $1 \%$ are other categories of people, namely 
parishioners who do not participate in spiritual life. $1 \%$ of respondents refused to answer this question.

It is worth noting that for $27 \%$ of respondents the religious confession of the beneficiaries is not important, which is not specific to faith-permeated organizations. However, $50 \%$ of respondents choose as beneficiaries parish members who participate in the spiritual life of the parish, or even members of the Christian religious community, irrespective of the parish, which, in general, makes the resulting model consistent to the features of faith-permeated organizations. It is also worth mentioning that there is a great share of respondents who place a value on parochialism, which accounts for $46 \%$ of all answers received, a percentage which accumulates respondents who considered that the beneficiaries are parishioners who frequently participate in the spiritual life with respondents who consider that the beneficiaries can be persons from the parish, without taking into account their religiosity. There is a slight correlation of those respondents $(+/-0.3)$ with people who have shown that they participate in the social-philanthropic activity motivated by the feeling of duty. This is probably due to the fact that the feeling of duty is stronger towards known persons - or, in any case, belonging to the parish of the respondents - than to peers in general.

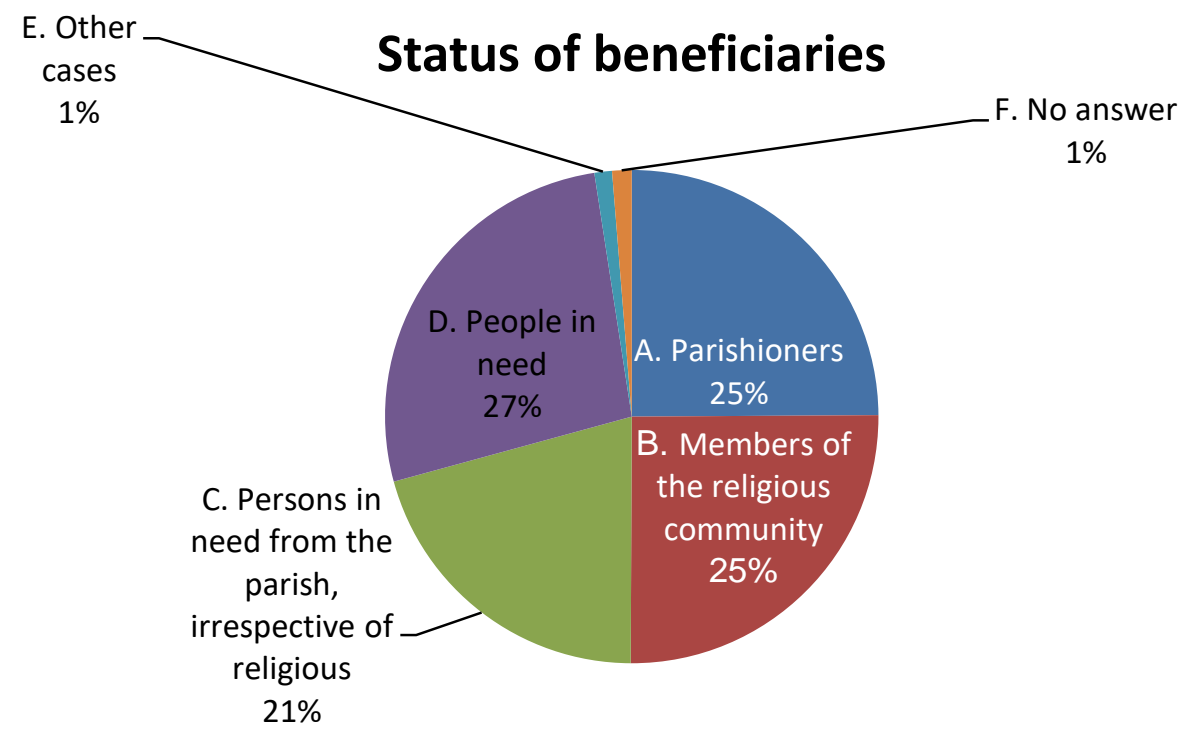

Figure 7 - The status of the beneficiaries targeted by the philanthropic activities carried out by the Romanian Orthodox Church 
Regarding the question where the respondents were asked to indicate, on a scale of 1 to 3, how involved they considered the Romanian Orthodox Church is, as a whole institution, in philanthropic activities $73 \%$ showed that the Romanian Orthodox Church is very involved in philanthropic activities, 24\% consider ROC only partially involved, and 3\% not involved at all.

The fact that such a large percentage of respondents show that the Church is involved in social-philanthropic activities may raise a question as to the possibility of a façade effect, in which the respondents outline what they think is expected of them, rather than what they really think. However, we consider that this is not the case here, because the structure of the sample included persons close to the Church, who participate in the socialphilanthropic activities of the Church, which makes us believe that the motivation of the massive response in favor of a very involved participation of the Church in social-philanthropic activities is given by the sense of selfesteem that arises from participation in such activities. However, a quarter of respondents consider that the involvement of the Romanian Orthodox Church in social-philanthropic activities, correlated with their own expectations towards the Church and of their own involvement, are not yet at maximum potential. The number of those who consider that there is no such involvement is insignificant, being only within 3\% of respondents - which shows that the social-philanthropic activity is well-known and acknowledged, but is interpreted differently, depending on the respondents' own expectations.

\section{The degree of involvement of the Romanian Orthodox Church in philanthropic activities}

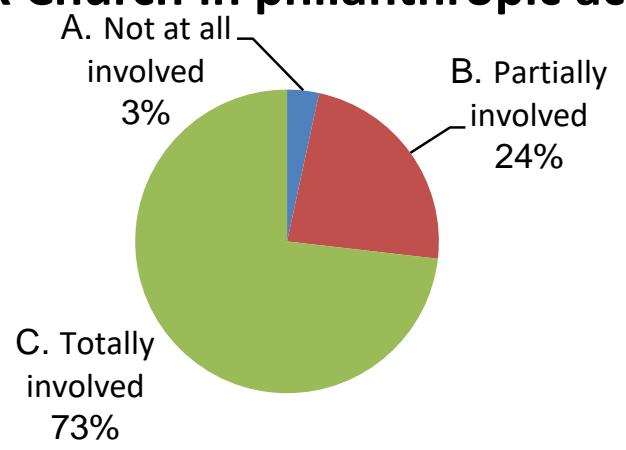

Figure 8 - The degree of involvement of the Romanian Orthodox Church in philanthropic activities 
Regarding the degree of involvement of the Romanian Orthodox Church as an institution in social assistance activities, 59\% of respondents show that the Romanian Orthodox Church is very involved in social assistance activities, 37\% say that it is partially involved, and 4\% that it is not involved at all.

We can see a $13 \%$ increase in the percentage of those who believe that the involvement of the Church in such activities can be substantially increased - and, at the same time, a decrease in optimism about the particularly broad involvement of the Romanian Orthodox Church in such activities. However, the percentage of those who declare themselves to be fully satisfied with the work of social assistance in the Church remains almost $60 \%$ of the respondents, which may still indicate a certain degree of façade effect, but also a sense of sufficiency for their own involvement. We consider that there is a partial overlap between the perception of specific assistance activities and the general philanthropic activities, which explains the high degree of satisfaction with both types of activities carried out by the Church. In fact, the distinction between assistential and philanthropic activities is somewhat forced, because even in the situation of secular social care, the provision of social benefits in the form of money or other goods is an integral part of social assistance. That is why the distinction between social assistance and philanthropy exclusively based on the licensing of services is partly inoperative, due, in our opinion, to inconsistencies in the legal framework of social assistance in Romania. Between specialists involved in such activities, the distinction between social assistance activities and philanthropic activities that are operationalized through the types of services offered and their accreditation/licensing is generally known and respected, and the operational definition that most participants in these social and philanthropic activities seem to work with is rather one related to professionalisation of services and volunteering for involvement, and not to the type of services provided. This distinction, operationalized according to the level of involvement and the level of professionalisation and involvement in the services offered, is coherent and consistent with accepted international definitions - both of philanthropy and of social assistance. 


\section{The degree of involvement of the Romanian Orthodox Church in social assistance activities}

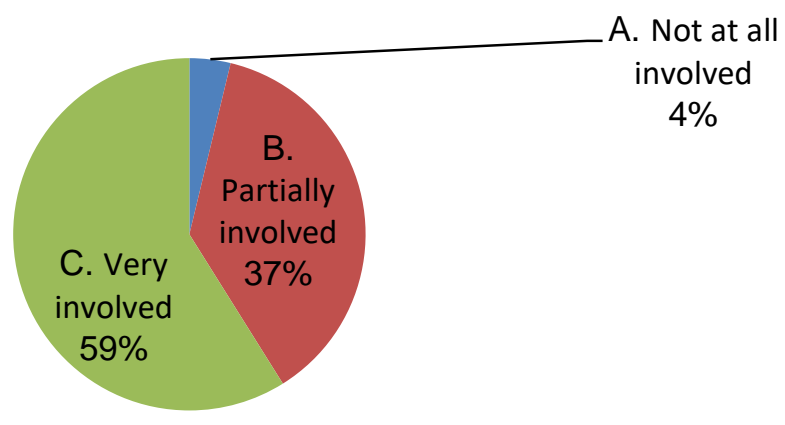

Figure 9- The degree of involvement of the Romanian Orthodox Church in social assistance activities

Particularly in their own parish, both as priest and parishioners, the respondents were asked to asses, on a scale of 1 to 3 , the degree of parish involvement in philanthropic activities, as they were asked previously for the Romanian Orthodox Church as an institution. 48\% of respondents show that the parish is very involved in philanthropic activities, $47 \%$ that it is partially involved, and 5\% that it is not involved at all.

Satisfaction with participation in philanthropic activities in their own parish is this time reduced to $50 \%$, respondents being aware of the possibility of the possibility to increase the degree of philanthropic activity in their own parish. If at the level of the whole Church, only $24 \%$ believed that involvement in such activities could increase - and this involvement is only partial - in the particular case of their own parish, this percentage reaches almost $50 \%$ of all respondents. Of course, we can not exclude a facade effect in this case, knowing that a good Christian expects to show humility and, if the degree of general involvement at Church level is hyperbolised, it is partially underestimated at parochial local level. However, the total number of those who are fully satisfied with the socialphilanthropic activity of parishes is close to $50 \%$, which makes us believe that the expressed opinion is the real one, the subjects being really satisfied with it, including their own participation. We notice a very small increase 
of those who are completely dissatisfied with the level of parish involvement in such activities - from 3\% who expressed this dissatisfaction in the general case of the Romanian Orthodox Church, to 5\% who express it when referring to their own parish.

\section{The degree of involvement of parishes in philanthropic activities}

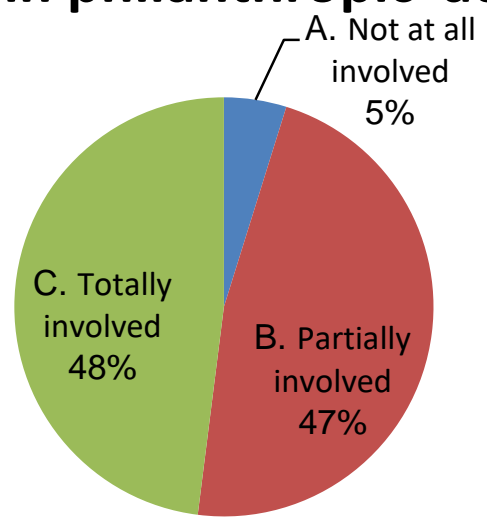

Figure 10 - The degree of involvement of parishes in philanthropic activities

Regarding the degree of parish involvement in social work, $52 \%$ responded that parishes are only partially involved in this type of activity, $31 \%$ of respondents consider that the parishes are very involved and $17 \%$ that they are not involved at all.

As far as the involvement in social assistance of the parishes is concerned, it is seen as partial by a percentage of respondents close to those who have expressed themselves the same regarding the philanthropic activity of their own parish. These observations, as well as those previously expressed, confirm the hypothesis according to which social-philanthropic activity and specialized social assistance are seen as a continuum, and the distinction between them is based on the level of participation, rather than the degree of professionalization of services.

We note a significant increase in the percentage of those who consider that their own parish is not at all involved in social assistance activities (17\% of respondents), compared to those who believe the parish is not involved in philanthropic activities - whose percentage is only $5 \%$. 
We place this difference on the basis of another operational distinction between philanthropy and social assistance, based on the distinction between services and gifts, the former being rather included in the sphere of philanthropy, and the latter in the sphere of social assistance itself. Of course, a number of social services that operate without being licensed are formally included in the philanthropy field, due to the need to comply with legal provisions that show that social assistance services can not be provided by unauthorized providers and/or unlicensed providers. In our opinion, this is a deficiency of the law, since although this is not the case in the social settlements of the Romanian Orthodox Church, there may be situations where a private social service provider conducts such unfiltered activities, classified as philanthropy, and not comply with standards of cost or staff required for licensing, but also with standards of care, therefore there may be cases of ill-treatment of beneficiaries.

\section{The degree of involvement of parishes in social assistance activities}

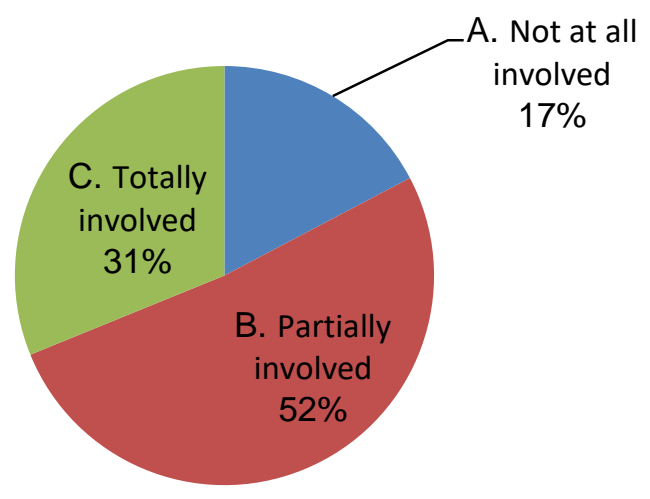

Figure 11 - The degree of involvement of parishes in social assistance activities

When they were asked to indicate whether there are some types of special social services provided by parishes, precisely social assistance services for emergency situations, 56\% of respondents indicated that there are no such services in their parish, $32 \%$ said there are such services, and $12 \%$ did not know whether or not such services exist in their parish, or refused to answer the question. 


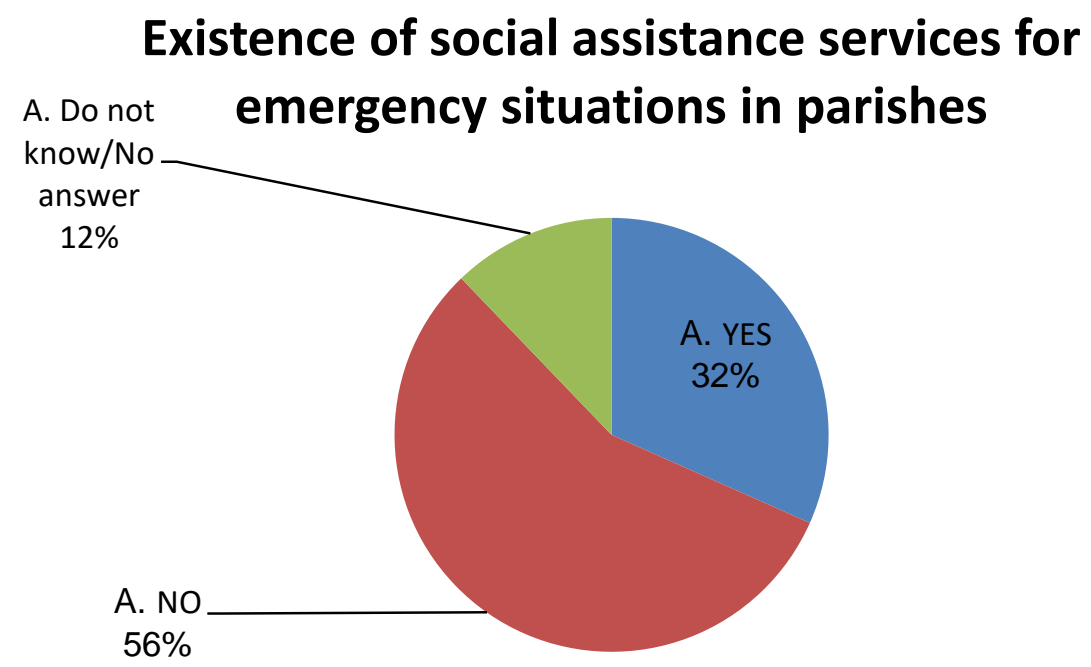

Figure 12 - Existence of social assistance services for emergency situations in parishes

Regarding the existence of residential social assistance services in parishes, $55 \%$ of respondents show that there are no such services in their parish, 31\% declare that such services exist and 14\% do not know the answer to this question, or do not want to answer.

Analyzing the two questions about the existence of different types of social assistance services (for emergency situations or residential services), it appears that $69 \%$ of respondents believe that there is at least one specialized social service in their parish. Comparing this response with the distribution of social services provided within the Iassi Archdiocese, we find that at least some of the respondents include among the specialized social assistance services either unlicensed social services (and which actually have the status of philanthropic activities) or a series of other activities of an assistential nature, such as counseling practices (including spiritual counseling). This observation supports the assertion of our $\mathrm{H} 4$ hypothesis regarding the perceived continuity between the socialphilanthropic activity and the specific social assistance. 


\section{Existence of residential social care services in parishes}

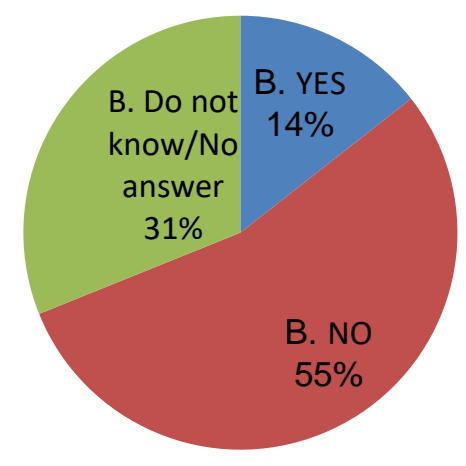

Figure 13 - Existence of residential social care services in parishes

In the next question, respondents were introduced to the concept of professionalization of social assistance services, such as the establishment/development of social assistance services for emergency situations or residential social care, or employing social workers or other professionals, after which they were asked to state whether they consider that a professionalization of the social serivices offered in parishes (where they are priests or parishioners) would be necessary according to the needs identified by parishioners. $62 \%$ of the respondents consider this professionalisation necessary, 23\% do not consider it necessary and 15\% did not provide an answer.

When the operational definition of philanthropy professionalization was set up as the establishment and development of residential social assistance services or assistance for emergency situations or by employing psychosocial professionals, this option was adopted by $62 \%$ of respondents, which means that professionalisation is seen as beneficial for the Church in general and for the respondent's own parish in particular, because quality social services can increase public trust in the Church. Of the $62 \%$ of respondents who consider such services to be necessary and $46 \%$ of those who believe that such services already exist in their own parish, there is a $16 \%$ difference indicating the openness of respondents and the appreciation for the need to develop social assistance services in a professional manner. 
This difference of $16 \%$ can be correlated with the $17 \%$ who indicated that the parish they are part of does not get involved at all in the social assistance services. In fact, there is a positive correlation between those who consider insufficient involvement of their parish in the social assistance activities and those who see it necessary to professionalize these services, to a degree of correlation of $+/-23 \%$.

The fact that $23 \%$ of respondents consider that there is no need for professionalisation can lead us to the conclusion that there is, among ROC representatives, a certain reticence towards professionalization, rather a fear that priests have that such professionalization may mean more tasks for them - either in the field of social assistance or in the management of social services provided by the parish. The consistent involvement of priests in social and philanthropic activity may lead to the impression of a deviation from liturgical activity in favor of social activity. The existence of a large number of non-responses, together with negative responses, raises the percentage of those who have a resistance to professionalisation of social services in the Church at $38 \%$. We place this resistance on the perception of modernization through professionalization as a possible risk of secularization. Correlating these results with the answers to the next question, regarding the risk of secularization, we see that only $15 \%$ of respondents are convinced of the existence of these risks, as another 17\% do not know what response to give. Thus, the H5 hypothesis, according to which the professionalization of social services is regarded as a risk of secularization, is only partially confirmed.

Other possible explanations for the refusal to professionalize social assistance services in the Church may be the desire to preserve philanthropic tradition through personalized charity, as being more suited for philanthropic services of a Christian nature, thus being consistent with the Church's tradition. Another explanation may be the fear that professionalisation can lead to a diminish of the emotional involvement of the Christian believer in the philanthropic act. However, the percentage of $23 \%$ of people who, for various reasons, consider that professionalization of social assistance in the Church is undesirable is high and, as such, leads us to the idea of a certain degree of conservatism among respondents, correlated with a certain caution regarding modernity, which is perceived as having diluted spiritual values. 


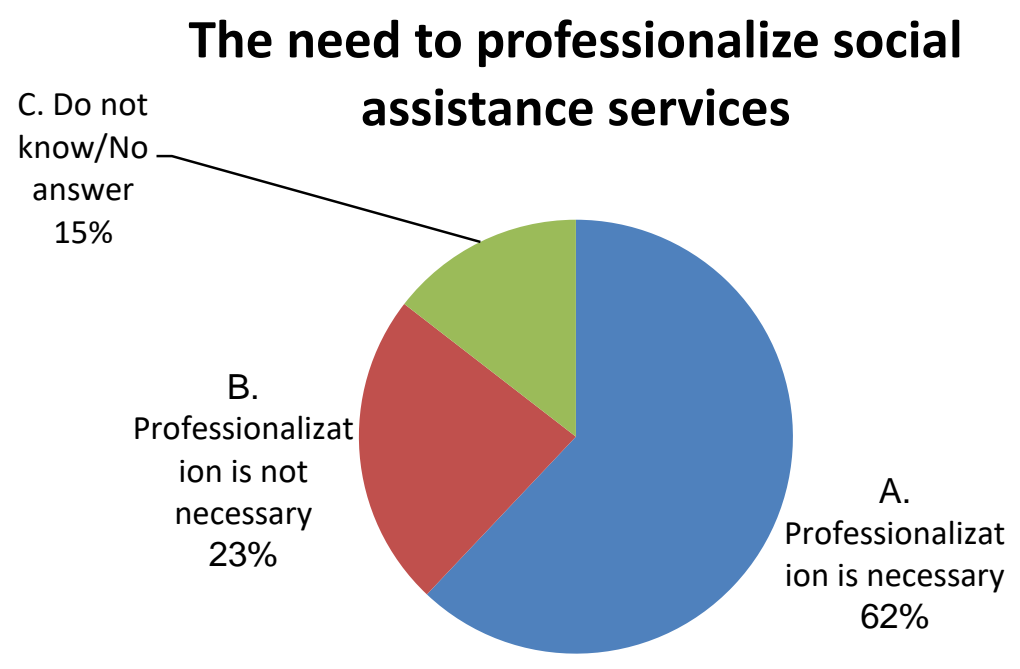

Figure 14 - The need to professionalize social assistance services

When asked if they think that switching from philanthropic activities to specialized social assistance activities can lead to the Romanian Orthodox Church secularization, the respondents considered, in a significant proportion, that the answer was "no" (68\%), while only $15 \%$ responded affirmatively, and 17\% appreciated whether they did not know how to respond or refused to express their point of view.

In apparent contradiction with the answers to the previous question, $68 \%$ of respondents do not see any danger of securitization in the professionalisation of social services. This rejection of the danger of secularization is due, in our opinion, to the confidence of respondents in the spiritual values of the assistential practices and to the fact that these practices, in the context of Christian social assistance, are infused by spiritual values such as altruism, the desire to serve the Other, compassion etc. This, again, confirms the hypothesis $\mathrm{H} 3$ about the existence of a spiritual dimension that adds to the professional values that characterize Christian social assistance. Secularization is, in the opinion of respondents, a danger only to a very small extent, due to the post-secular perspective from which social services are approached within ROC and that does not deny their professional dimension, as long as the spiritual dimension is added to it. Even if the danger of secularization is minimized, the answers to the previous question, that indicate that although it is accepted by the 
majority of respondents, the professionalization of social assistance remains questionable for a large percentage of them, indicates that the post-secular perspective is adopted at a cognitive level but not fully understood as an actual reality of our times.

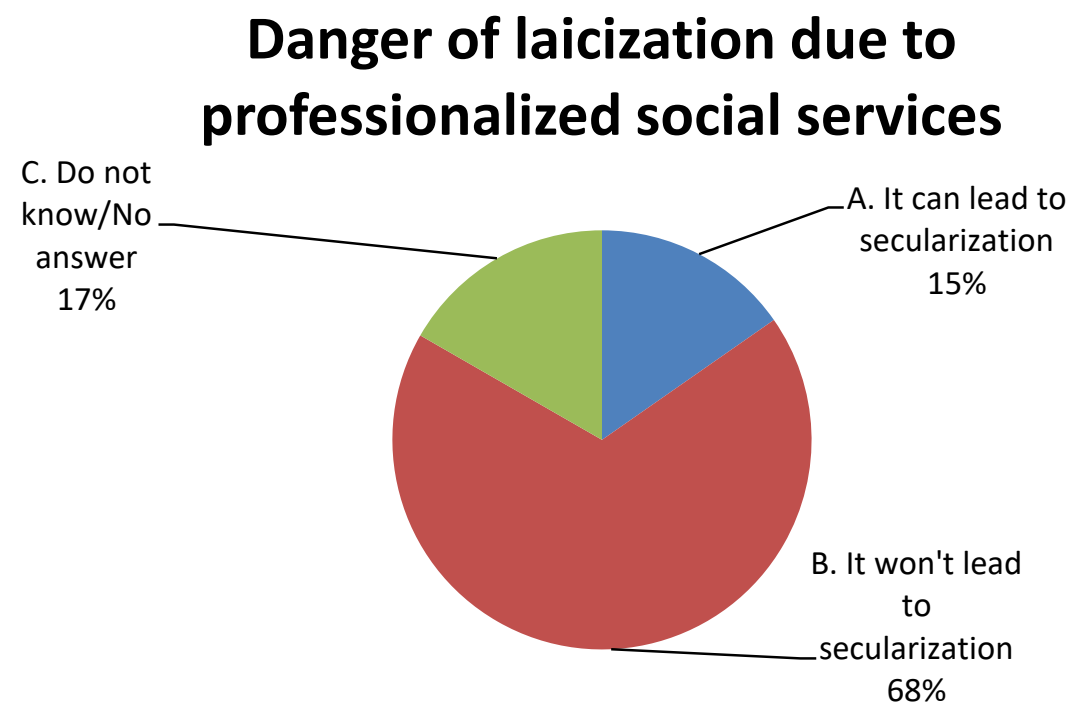

Figure 15 - Danger of secularization for the Romanian Orthodox Church by moving from philanthropy to specialized social assistance

When asked if they consider that there is a certain specificity of the social assistance provided by the religious institutions in the Romanian Orthodox Church compared to those offered by the Romanian state or other secular organizations, $43 \%$ of respondents stated that the answer is "yes", because social workers affiliated with the Romanian Orthodox Church are more involved in what they do than those affiliated with secular organizations, $32 \%$ answered "yes", because the Church has a non-formal help network, 9\% did not want to respond, $8 \%$ believe the answer is "no", because the Church does not have as much resources as the state, and $8 \%$ have strengthened this position, as they believe there is no certain specificity of the social assistance developed by the Romanian Orthodox Church, as opposed to that offered by the state or secular organizations, but because of another reason, namely that standards for licensing of services are the same for both the Romanian Orthodox Church and secular services.

The answers to this question again confirm the $\mathrm{H} 3$ hypothesis, and it is obvious that the majority $(75 \%)$ consider that there is a difference 
between secular social assistance and Christian social assistance provided by the Church. The fact that $8 \%$ of respondents emphasize common standards of universal practice as common, regardless of the assumed spiritual value of social practice, does not minimize the Christian specificity of social assistance provided by the Church, but rather emphasizes the coherence and fairness of social assistance offered within the Church, as compared to existing good practices at a state level.

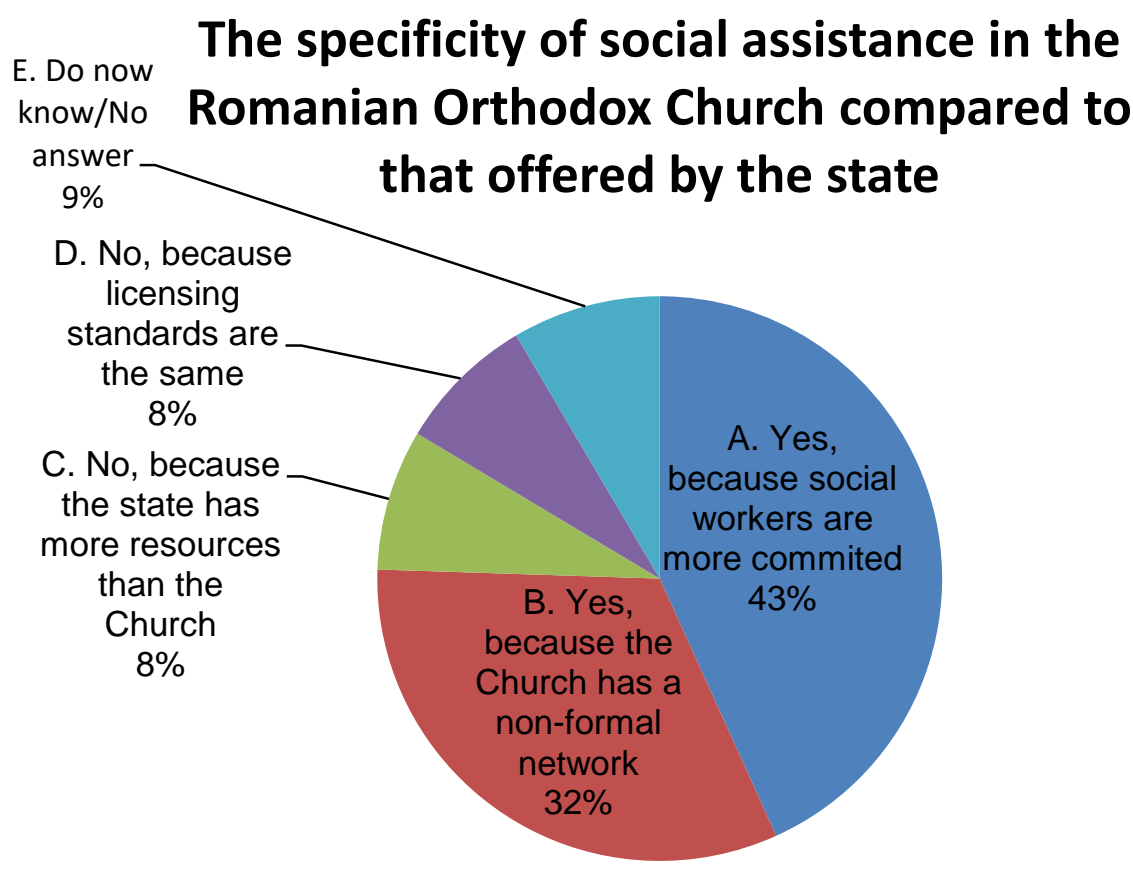

Figure 16 - The specificity of social assistance in the Romanian Orthodox Church compared to that offered by the state

\section{Discussions and limitations}

Regarding the size and statistical relevance of the sample, a total of 577 interviewes are likely to offer a margin of error of $+/-5 \%$ and a confidence level of the study of $95 \%$. With regard to the structure of the sample, 439 men $(76 \%)$ and 136 women $(23 \%)$ participated in the survey, and the higher number of men is due partly to the specificity of the sampling process, because in the first stage the questionnaire was applied only to priests, therefore to male respondents. Considering the small number of 
questioned priests who agreed to apply the questionnaire to people involved in the social assistance/philanthropy services from the parish they belonged to, we can advance the hypothesis that the number of women involved in the social-philanthropic activity of the Romanian Orthodox Church is higher than the percentage of women in the sample, which may constitute a limitation of the research.

\section{Conclusions}

Hypothesis H1, according to which the social-philanthropic activity of the Romanian Orthodox Church is correlated with the liturgical activity, is validated because there is a significant correlation between the participation of people in social philanthropic activity and their participation in religious rituals and practices of the Church.

Hypothesis $\mathrm{H} 2$, according to which the social-philanthropic activity of the Romanian Orthodox Church is based on the model of faithpermeated organizations, has been confirmed, as the study highlighted the way that benefciaries are selected and the correlation between the religiosity of persons involved in the provision of social and philanthropic services within the Romanian Orthodox Church, as well as the concerns with regard to possible secularization of practice, which are in line with the faithpermeated organization model.

Hypothesis H3, according to which the professionalization of socialphilanthropic and assistential services within the Romanian Orthodox Church is partially confirmed, most of respondents noticing that the spiritual dimension is added to the professional practice itself, the model of Christian social assistance being convergent with that described in the international literature and appropriate to the post-secular society.

Hypothesis H4, according to which social-philanthropic activity and specialized social assistance are seen as a continuum, and the distinction between them is based on the level of participation rather than on the professionalisation of services, is partially confirmed, the continuity between the two dimensions being highlighted by analyzing answers to questions about parish involvement in social work.

Hypothesis I5, according to which the professionalization of social services is regarded as a risk of secularization, is only partially confirmed, in the sense that the respondents are aware of the existence of this risk, but it is not appreciated as being significant. There is a reluctance about the need to professionalize social assistance services, which can be attributed to the reluctance towards the current society, which is too little inclined towards 
Philanthropical Practices and Professionalization of Social Assistance in the ... Polixenia NISTOR

developing professionalism in social services based on spiritual values outside the particular circumstances created by faith-based organizations. There is a mistrust in the post-secular society as a model of society that combines the values of humanist professionalism with deep Christian spiritual values.

\section{Acknowledgement}

The article is part of the doctoral thesis entitled Professionalization of Charity in the Archdiocese of Iassi of the Romanian Orthodox Church, submitted for public defending in 2019 within the Doctoral School of Philosophy and SocialPolitical Sciences of "Al. I. Cuza "University of Iasi, main domanin: sociology.

\section{References}

Braeckman, A. (2009). Habermas and Gauchet on religion in postsecular society. A critical assessment. Continental Philosophy Review, 42(3), 279-296.

Brieskorn, N. (2010). On the attempt to recall a relationship. In N. Brieskorn, J. Habermas, M. Reder, F. Ricken \& J. Schmidt (Eds.), An awareness of what is missing. Faith and reason in a post-secular age (pp. 24-35). Cambridge, UK: Polity.

Cace, S., Cace, C., \& Nicolăescu, V. (2011). The social programs run by the Romanian Orthodox Church during the period of the economic crisis. Revista de Cercetare și Intervenție Socială, 35, 28-45.

Cnaan, R. A., \& Boddie, S. C. (2002). Charitable choice and faith-based welfare: A call for social work. Social Work, 47(3), 224 to 235. doi:10.1093/sw/47.3.224

Cojocaru, D., Cojocaru, S.., \& Sandu, A. (2011). The role of religion in the system of social and medical services in post-communism Romania. Journal for the Study of Religions and Ideologies, 10(28), 65-83.

Frunză, S. (2012). Political ethics between biblical ethics and the mythology of the death of God. Journal for the Study of Religions and Ideologies, 33, 206-231.

Gavriluță, C. (2011). The sense of value in a desacralized world. Journal for the Study of Religions and Ideologies, 10(28), 234-239.

Gavriluță, N. (1998). Mentalități și ritualuri magico-religioase [Magic-religious mentalities and rituals]. Iași, Romania: Polirom.

Gavriluță, N. (2002). On tolerance and acceptance of the Other. Journal for the Study of Religions and Ideologies, 1(3), 22-27.

Giligan, P., \& Furness, S. (2005). The role of religion and spirituality in social work practice: Views and experiences of social workers and students. British Journal of Social Work, 36(4), 617-637. doi:10.1093/bjsw/bch252 
Habermas, J. (2008). Notes on a post secular society. Retrieved from http://www.signandsight.com/features/1714.html

Nistor, P. (2018a). The charitable foundations of social assistance. Eastern European Journal of Medical Humanities and Bioethics, 2(2), 15-30. doi:10.18662/eejmhb/12

Nistor, P. (2018b). The faith-based organization in the post-secular society. Logos Universality, Mentality, Education, Novelty: Social Sciences, 7(2), 17-35. doi:10.18662/lumenss/07

Nistor, P. (2018c). Social services offered by faith-based organizations in the postsecular society. Logos, Universality, Mentality, Education, Novelty: Social Sciences, 7(2), 17-35. doi:10.18662/lumenss/07

Nistor, P. (2019). Profesionalizaria carităţii în Arbiepiscopia Iaşilor a Bisericii Ortodoxe Române [Professionalization of charity in the Archdiocese of Iaşi of the Romanian Orthodox Church], doctoral dissertation, filed for public defending at the Doctoral School of Philosophy and Social-Political Sciences of "Al. I. Cuza "University of Iasi, main field: sociology.

Reder, M. (2010). How far can faith and reason be distinguished? In N. Brieskorn, J. Habermas, M. Reder, F. Ricken \& J. Schmidt, An awareness of what is missing. faith and reason in a post-secular age (pp. 36-50). Cambridge, USA: Polity.

Ricken, F. (2010). Postmetaphysical reason and religion. In N. Brieskorn, J. Habermas, M. Reder, F. Ricken \& J. Schmidt, An awareness of what is missing. faith and reason in a post-secular age (pp. 51-58). Cambridge, USA: Polity.

Sandu, A., \& Caras, A. (2013). Deconstruction of charity. Postmodern ethical approaches. Journal for the Study of Religions and Ideologies, 12(3), 72-99.

Sider, R. J., \& Unruh, H. R. (2004). Typology of religious characteristics of social service and educational organizations and programs. Nonprofit and Voluntary Sector Quarterly, 33(1), 109-134. doi:10.1177/0899764003257494

Ticu, D. (2013). Axiological dimensions involved in the public policies process. European Journal of Science and Theology, 9(2), 57-64.

U.S. Department of Health \& Human Services (1996). Personal Responsibility and Work Opportunity Reconciliation Act of 1996. Retrieved from https://aspe.hhs.gov/report/personal-responsibility-and-workopportunity-reconciliation-act-1996

Van der Merve, W., Swart, I., \& Hendriks, J. (2014). Faith-based organisations in the context of social welfare and development in South Africa: Towards a conceptualization. Social Work/Maatskaplike Werk, 45(2), 125-139. doi:10.15270/45-2-210 